\title{
PENGARUH PEMBELAJARAN DENGAN PENDEKATAN VISUAL THINKING TERHADAP SIKAP SISWA
}

\author{
Erdawati Nurdin \\ Program Studi Pendidikan Matematika FKIP UIR \\ Jl. KH. Nasution Km. 11 Perhentian Marpoyan, Pekanbaru \\ da_1910@yahoo.com
}

\begin{abstract}
ABSTRAK
Penelitian ini merupakan penelitian kualitatif yang mengkaji pengaruh pendekatan visual thinking terhadap sikap siswa. Data pada penelitian ini diperoleh dari angket yang diisi oleh siswa setelah mendapatkan pembelajaran matematika dengan pendekatan visual thinking. Angket skala sikap yang digunakan merujuk kepada skala Likert. Analisis sikap siswa dilakukan dengan membandingkan rerata skor sikap siswa dengan skor netralnya pada setiap pernyataan. Berdasarkan hasil penelitian yang telah dilakukan diperoleh kesimpulan bahwa penerapan pembelajaran dengan pendekatan visual thinking memberikan pengaruh positif terhadap sikap siswa.
\end{abstract}

Kata Kunci : Pendekatan Visual Thinking, Sikap Siswa, Skala Likert

\begin{abstract}
This is a qualitative research that discuss about the effect of visual thinking approach toward students' attitude. The data of research were obtained from questionnaires that completed by students after getting mathematics learning by using visual thinking approach. The attitude scale questionnaires that used refer to Likert scale. The analysis of students' attitude is done by comparing students' mean score with its' neutral score in every statements. Based on the result of research that has been done, it can be concluded that learning by using visual thinking approach gives the positive effect to the students' attitude.
\end{abstract}

Key Words: Visual Thinking Approach, Students’ Attitude, Likert Scale.

\section{Pendahuluan}

Matematika memiliki peranan
yang sangat penting dalam
perkembangan ilmu pengetahuan dan
teknologi masa kini. Oleh karena itu
matematika dipelajari pada semua
jenjang pendidikan, dengan harapan
pembelajaran matematika harus dapat

menumbuhkembangkan kemampuan dan pribadi siswa yang sejalan dengan tuntutan kehidupan masa depan (Hodiyah, 2009). Banyak faktor yang mempengaruhi kemampuan dan hasil belajar matematika, baik dari guru, sarana dan prasarana, serta dari siswa itu sendiri, 
salah satunya adalah sikap siswa terhadap matematika.

Sikap menurut Ruseffendi (2006) adalah sesuatu yang berkenaan dengan hal yang dipercayai, hayati, dan rasakan oleh seseorang. Sikap sebagai suatu kesatuan kognisi yang mempunyai valensi dan akhirnya berintegrasi ke dalam pola yang lebih luas. Sikap belum merupakan tindakan/aktivitas, melainkan berupa kecenderungan (tendency) atau predisposisi tingkah laku.

Sikap umumnya akan mencerminkan bagaimana seseorang merasakan sesuatu. Misalnya jika seseorang siswa menyatakan "saya menyukai pelajaran matematika" berarti dia sedang mengungkapkan sikap terhadap pelajaran matematika tersebut. Dengan sikap yang baik seseorang akan bersedia mengikuti suatu kegiatan dengan baik tanpa perasaan yang tertekan dan tidak senang. Sehingga untuk dapat membuat pelajaran matematika menyenangkan, tugas guru adalah menciptakan image dan atmosfer pembelajaran yang akan berakibat pada pembentukan sikap yang baik pada siswa.

Sikap siswa yang besar berbanding lurus dengan peningkatan prestasi belajarnya. Sebagaimana pendapat Dalyono (Djamarah, 2008) mengungkapkan bahwa minat belajar yang besar cenderung menghasilkan prestasi yang tinggi, sebaliknya, minat belajar yang kurang cenderung menghasilkan prestasi yang rendah.

Agar siswa dapat menerima pelajaran matematika atau memberikan respon yang positif setelah mengikutinya, terlebih dahulu guru dapat menanamkan sikap positif kepada siswa terhadap matematika. Dengan kata lain sikap positif siswa terhadap matematika harus diperhatikan selama proses pembelajaran matematika sehingga setelah siswa belajar matematika, sikap siswa akan lebih positif terhadap matematika itu sendiri.

Dengan demikian, agar dapat menumbuhkan sikap positif terhadap matematika, yang perlu diperhatikan antara lain penyampaian matematika dirancang sehingga menyenangkan dan mudah dipahami. Salah satu variasi pembelajaran yang diharapkan mampu menumbuhkan sikap positif siswa adalah pendekatan visual thinking.

Berpikir visual (visual thinking) dapat menjadi sumber alternatif bagi siswa bekerja dalam matematika. Sebagaimana yang diungkapkan oleh Thornton (2001) bahwa visual thinking dalam pembelajaran matematika sekolah dapat menyediakan pendekatan yang sederhana, mudah, luwes dan sangat ampuh untuk mengembangkan penyelesaian matematis dan pemecahan masalah serta dalam proses pembuatan koneksi. 
Secara sadar ataupun tidak, kita sering berpikir secara visual (visual thinking) dalam kehidupan sehari-hari. Misalnya, ketika ditanyai alamat suatu tempat, kita akan lebih mudah menyampaikan informasi tentang alamat tersebut dengan menuangkannya dalam bentuk peta (gambar).

Melalui pembelajaran dengan pendekatan visual thinking, siswa dapat aktif menggunakan alat peraga, media pembelajaran maupun lingkungan sebagai sumber belajar. Menurut Wahidin (2010) penggunaan alat peraga ataupun benda-benda konkrit sebagai sumber belajar dapat membuat aktif dalam mengkonstruksikan maupun mengorganisir belajarnya sendiri. Hal ini dapat mengatasi rutinitas pembelajaran yang membosankan. Siswa tidak hanya dapat memanfaatkan beragam sumber belajar, melainkan pembelajaran yang dilaluinya akan dirasakan sebagai belajar sambil bermain, dan ini sangat tepat dengan kondisi perkembangan mental siswa di sekolah menengah pertama. Diharapkan dengan pendekatan visual thinking dalam pembelajaran matematika dapat menjadi jembatan yang mampu menumbuhkan sikap positif siswa terhadap matematika.

Berdasarkan uraian diatas maka penelitian ini difokuskan pada pengkajian pengaruh pendekatan pembelajaran visual thingking terhadap sikap siswa.

\section{Metode Penelitian}

Tujuan penellitian ini adalah untuk melihat pengaruh pendekatan pembelajaran visual thinking terhadap sikap siswa. Penelitian ini melibatkan sebuah kelas yang dalam proses pembelajarannya diberikan perlakuan berupa pendekatan visual thinking. Pembelajaran dilakukan selama 6 (enam) pertemuan, ditambah satu pertemuan ujian harian (UH).

Populasi pada penelitian ini adalah siswa Madrasah Tsanawiyah Tembilahan tahun pelajaran 2011-2012. Karena tidak mungkin mempelajari semua yang ada pada populasi, maka peneliti menggunakan sampel yang diambil dari populasi. Penentuan sampel dilakukan dengan cara purposive sampling, yaitu teknik pengambilan sampel berdasarkan pertimbangan tertentu (Sugiyono, 2010). Kelas eksperimen dan kelas kontrol yang merupakan sampel pada penelitian ini dipilih berdasarkan pertimbangan guru matematika di sekolah tersebut dengan mengambil kelas yang sudah ada. Hal ini juga dikarenakan pihak sekolah tidak mengizinkan terjadinya pengacakan terhadap kelas yang sudah ada disebabkan kekhawatiran dapat mengganggu proses pembelajaran. Sampel yang dipilih dalam penelitian ini adalah siswa kelas VIII salah satu Madrasah Tsanawiyah di Tembilahan. Subjek penelitian ini adalah siswa kelas 
VIII.1 semester genap tahun pelajaran 2011/2012 yang berjumlah 31 orang.

Instrumen yang digunakan pada penelitian ini adalah instrumen non-tes berupa angket skala sikap siswa. Skala sikap siswa bertujuan untuk mengetahui sikap siswa terhadap proses pembelajaran dengan pendekatan visual thinking. Dalam penelitian ini angket skala sikap disusun dengan mengacu pada skala Likert. Skala Sikap Likert tersusun atas beberapa pernyataan positif (favorable statements) dan pernyataan negatif (unfavorable statements) yang mempunyai lima kemungkinan jawaban (option) dengan kategori yang continuum, dari mulai jawaban sangat setuju (strongly agree) sampai sangat tidak setuju (strongly disagree). Pada angket disediakan empat skala pilihan yaitu: Sangat Setuju (SS), Setuju (S), Tidak Setuju (TS) dan Sangat Tidak Setuju (STS). Pilihan ragu-ragu (RR) tidak digunakan, untuk menghindari jawaban aman, sekaligus mendorong siswa untuk menunjukkan keberpihakannya terhadap pernyataan yang diajukan.

Dalam menganalisis hasil skala sikap, skala kualitatif tersebut diganti kedalam skala kuantitatif. Pernyataan positif dan negatif diberi skor dengan cara yang berbeda. Untuk pernyataan positif, pemberian skornya adalah SS diberi skor 4, S diberi skor 3, TS diberi skor 2 dan STS diberi skor 1. Sebaliknya untuk pernyataan yang bersifat negatif, pemberian skornya adalah SS diberi skor 1, S diberi skor 2, TS diberi skor 3 dan STS diberi skor 4.

Langkah-langkah pengolahan data skala sikap siswa yang dilakukan pada penelitian ini adalah:

a. Menghitung frekuensi masingmasing skor pernyataan.

b. Menghitung proporsi untuk setiap frekuensi skor.

c. Menjumlahkan proporsi secara berurutan untuk setiap respon, sehingga diperoleh proporsi kumulatif.

d. Menentukan nilai tinggi densitas untuk setiap nilai z.

e. Menghitung SV (Scale Value) dengan rumus:

SV

$=\frac{\text { density at lower limit }- \text { density at upper limit }}{\text { area below upper limit }- \text { area below lower limit }}$

f. Menentukan nilai transformasi dengan rumus: $Y=S V+\left[1+\left|S V_{\min }\right|\right]$

Analisis sikap siswa dilakukan dengan membandingkan rerata skor sikap siswa dengan skor netralnya pada setiap pernyataan. Pada angket skala sikap tidak terdapat pilihan netral, sehingga skor netral setiap pernyataan diperoleh dari rerata skor yang telah ditransformasikan $(Y)$. Sikap siswa dikatakan positif jika rerata skor sikap siswa untuk setiap pernyataan lebih besar dibanding skor netral. Sebaliknya, sikap siswa dikatakan 
negatif apabila rerata skor sikap siswa lebih kecil dari skor netralnya.

\section{Hasil Penelitian dan Pembahasan}

Seperti yang telah diungkapkan bahwa pada penelitian ini angket skala sikap disusun dengan mengacu pada skala Likert. Pada angket disediakan empat skala pilihan yaitu: Sangat Setuju (SS), Setuju (S), Tidak Setuju (TS) dan Sangat Tidak Setuju (STS). Pilihan raguragu (RR) tidak digunakan, untuk menghindari jawaban aman, sekaligus mendorong siswa untuk menunjukkan keberpihakannya terhadap pernyataan yang diajukan.

Dalam menganalisis hasil skala sikap, skala kualitatif tersebut diganti kedalam skala kuantitatif. Pernyataan positif dan negatif diberi skor dengan cara yang berbeda. Untuk pernyataan positif, pemberian skornya adalah SS diberi skor 4, S diberi skor 3, TS diberi skor 2 dan STS diberi skor 1. Sebaliknya untuk pernyataan yang bersifat negatif, pemberian skornya adalah SS diberi skor 1, S diberi skor 2, TS diberi skor 3 dan STS diberi skor 4.

Analisis sikap siswa dilakukan dengan membandingkan rerata skor sikap siswa dengan skor netralnya pada setiap pernyataan. Perhitungan skala sikap siswa ini menggunakan bantuan Microsoft Office Excel 2007.

Pada angket skala sikap tidak terdapat pilihan netral, sehingga skor netral setiap pernyataan diperoleh dari rerata skor yang telah ditransformasikan. Sikap siswa dikatakan positif jika rerata skor sikap siswa untuk setiap pernyataan lebih besar dibanding skor netral. Sebaliknya, sikap siswa dikatakan negatif apabila rerata skor sikap siswa lebih kecil dari skor netralnya.

Hasil analisis data skala sikap siswa terhadap pendekatan pembelajaran visual thinking dapat dilihat pada Tabel berikut :

Tabel Hasil Analisis Data Skala Sikap Siswa

\begin{tabular}{|c|c|c|c|c|c|c|c|c|c|c|}
\hline \multirow{2}{*}{$\begin{array}{c}\text { No } \\
\text { Soal }\end{array}$} & \multirow{2}{*}{$\begin{array}{c}\text { Sifat } \\
\text { Pernyataan }\end{array}$} & \multicolumn{4}{|c|}{ Jawaban } & \multicolumn{2}{|c|}{ Skor Netral } & \multicolumn{2}{|c|}{ Skor Sikap } & \multirow[t]{2}{*}{ Ket } \\
\hline & & SS & $\mathbf{S}$ & TS & STS & Item & Klasf & Item & Klasf & \\
\hline \multirow[t]{2}{*}{1} & Positif & 25 & 6 & 0 & 0 & 0,93 & 1,34 & 2,40 & 2,25 & Positif \\
\hline & Skor & 2,74 & 1,00 & 0,00 & 0,00 & & & & & \\
\hline \multirow[t]{2}{*}{2} & Positif & 28 & 3 & 0 & 0 & 0,98 & & 2,74 & & Positif \\
\hline & Skor & 2,92 & 1,00 & 0,00 & 0,00 & & & & & \\
\hline \multirow[t]{2}{*}{3} & Negatif & 8 & 17 & 6 & 0 & 1,74 & & 2,40 & & Positif \\
\hline & Skor & 3,64 & 2,31 & 1,00 & 0,00 & & & & & \\
\hline \multirow[t]{2}{*}{4} & Negatif & 2 & 21 & 6 & 2 & 2,76 & & 2,98 & & Positif \\
\hline & Skor & 4,86 & 3,24 & 1,94 & 1,00 & & & & & \\
\hline \multirow[t]{2}{*}{5} & Negatif & 1 & 14 & 15 & 1 & 0,12 & & 0,31 & & Positif \\
\hline & Skor & 5,38 & $-3,65$ & 3,98 & $-5,22$ & & & & & \\
\hline \multirow[t]{2}{*}{6} & Positif & 16 & 15 & 0 & 0 & 0,90 & & 1,82 & & Positif \\
\hline & Skor & 2,58 & 1,00 & 0,00 & 0,00 & & & & & \\
\hline \multirow[t]{2}{*}{7} & Positif & 13 & 18 & 0 & 0 & 0,90 & & 1,67 & & Positif \\
\hline & Skor & 2,59 & 1,00 & 0,00 & 0,00 & & & & & \\
\hline \multirow[t]{2}{*}{8} & Positif & 13 & 17 & 1 & 0 & 1,90 & & 3,14 & & Positif \\
\hline & Skor & 4,06 & 2,55 & 1,00 & 0,00 & & & & & \\
\hline
\end{tabular}




\begin{tabular}{|c|c|c|c|c|c|c|c|c|}
\hline \multirow[t]{2}{*}{9} & Negatif & 11 & 16 & 0 & 4 & \multirow[t]{2}{*}{1,75} & \multirow[t]{2}{*}{2,66} & \multirow[t]{2}{*}{ Positif } \\
\hline & Skor & 3,67 & 2,32 & 0,00 & 1,00 & & & \\
\hline \multirow[t]{2}{*}{10} & Positif & 22 & 9 & 0 & 0 & \multirow{2}{*}{0,91} & \multirow[t]{2}{*}{2,17} & \multirow[t]{2}{*}{ Positif } \\
\hline & Skor & 2,65 & 1,00 & 0,00 & 0,00 & & & \\
\hline \multirow[t]{2}{*}{11} & Positif & 24 & 7 & 0 & 0 & \multirow[t]{2}{*}{0,92} & \multirow[t]{2}{*}{2,32} & \multirow[t]{2}{*}{ Positif } \\
\hline & Skor & 2,70 & 1,00 & 0,00 & 0,00 & & & \\
\hline \multirow[t]{2}{*}{12} & Negatif & 9 & 12 & 8 & 2 & \multirow[t]{2}{*}{2,32} & \multirow[t]{2}{*}{2,36} & \multirow[t]{2}{*}{ Positif } \\
\hline & Skor & 3,55 & 2,42 & 1,00 & 2.32 & & & \\
\hline
\end{tabular}

Dari tabel diatas menunjukkan bahwa seluruh butir pernyataan menunjukkan sikap positif siswa, sehingga dapat disimpulkan secara umum bahwa sikap siswa terhadap pendekatan pembelajaran visual thinking adalah positif.

Menurut Ruseffendi (2006) sikap positif siswa terhadap matematika berkorelasi dengan prestasi belajar, termasuk kemampuan pemecahan masalah dan koneksi matematis. Sikap mental positif adalah salah satu kepercayaan yang dapat meningkatkan melalui proses-proses pemikiran yang optimis. Nicolaidou dan Philippou (2002) menyebutkan bahwa sikap memiliki hubungan yang erat dengan kemampuan matematis siswa. Ditambahkan oleh Mohd dan Mahmood (2011) bahwa sikap positif, berupa kesabaran, rasa percaya diri dan harapan memberikan kontribusi terhadap pencapaian dalam matematika.

Ketika proses belajar mangajar terlihat keantusiasan siswa terhadap pembelajaran yang dilakukan. Siswa terlihat bersemangat mengikuti kegiatan pembelajaran. Misalnya, pada tahapan looking dan seeing, siswa berkomentar bahwa pembelajaran yang dilakukan sangat menyenangkan dan tidak membosankan karena menggunakan berbagai media pembelajaran visual, mulai dari gambar, tabel, diagram, model bangun ruang sisi datar aneka bentuk dan warna hingga video animasi mengenai bangun ruang sisi datar. Salah satu media pembelajaran yang digunakan terlihat pada gambar berikut:

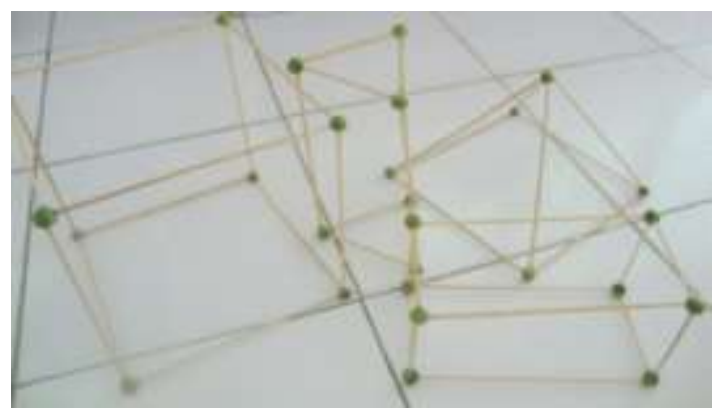

Gambar 1. Kerangka Beberapa Bangun Ruang Sisi Datar

Gambar 1 diatas adalah gambar kerangka kubus, balok, prisma segitiga dan limas segiempat. Kerangka-kerangka tersebut dibuat dari tusuk sate dan buah rimbang. Menggunakan kerangka-kerangka tersebut, siswa dapat melihat banyaknya rusuk dan titik sudut masing-masing bangun ruang.

Siswa juga bersungguh-sungguh ketika melalui tahapan imagining, hasil pemikiran mereka dituangkan dalam gambar. Hal ini dapat dilihat dari gambar berikut: 


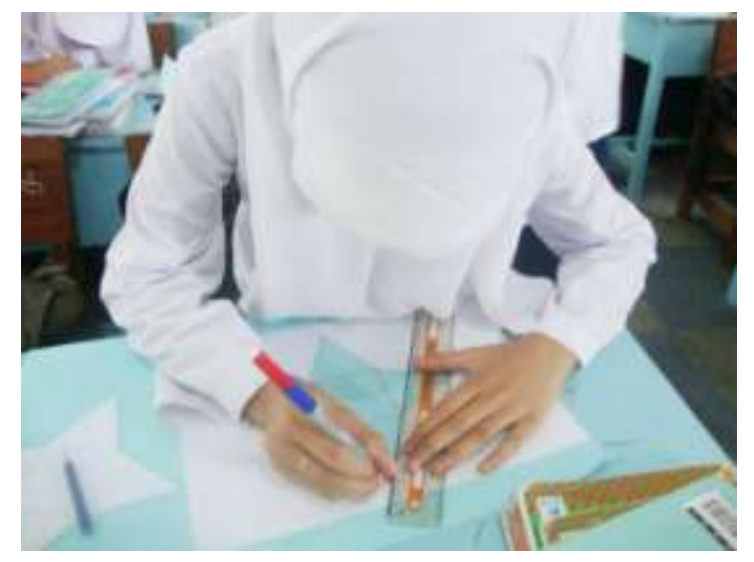

Gambar 2. Seorang Siswa sedang
Terlihat pada Gambar 2 seorang siswa yang sedang asyik menuangkan pemikirannya mengenai jaring-jaring limas segiempat dengan melukiskannya ke sebuah kertas manila. Gambar-gambar jaring-jaring bangun ruang sisi datar yang dilukis siswa saat pembelajaran visual thinking dapat dilihat pada gambar berikut ini:

Menggambar Jaring-Jaring Limas

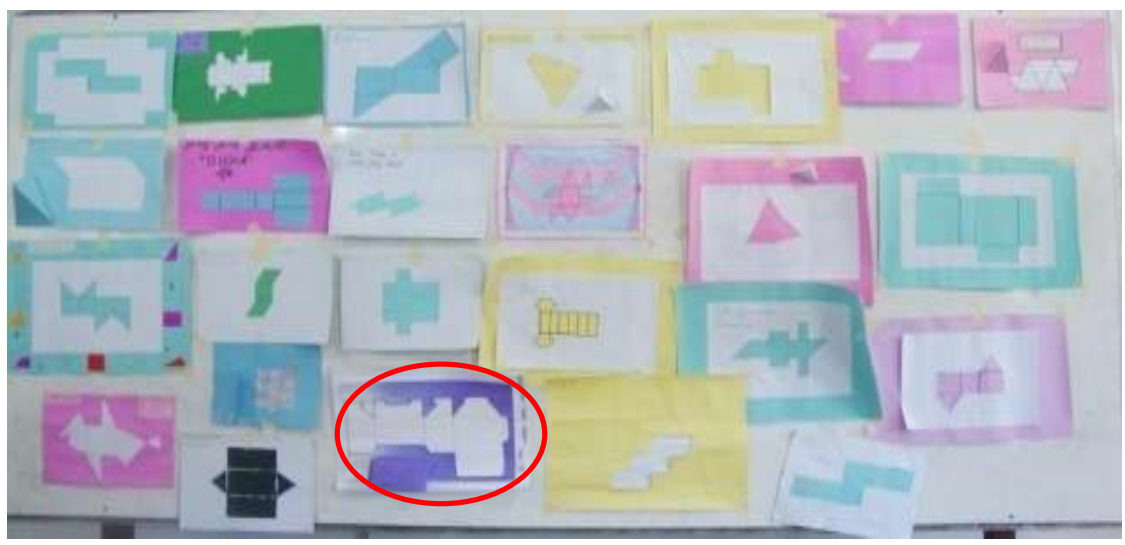

Gambar 3. Jaring-Jaring Bangun Ruang Sisi Datar

Gambar 3 menunjukkan bahwa siswa telah mampu menggambarkan berbagai bentuk jaring-jaring kubus, balok, prisma dan limas. Siswa mampu mengembangkan kreativitasnya dalam menggambar jaring-jaring bangun ruang sisi datar, walapun masih ada yang salah menggambarnya (gambar yang dilingkari). Keaktifan siswa terlihat ketika pembelajaran, pada tahapan telling and showing siswa antusias menyajikan dan menyampaikan ide-idenya di depan kelas seperti terlihat pada gambar di bawah ini:

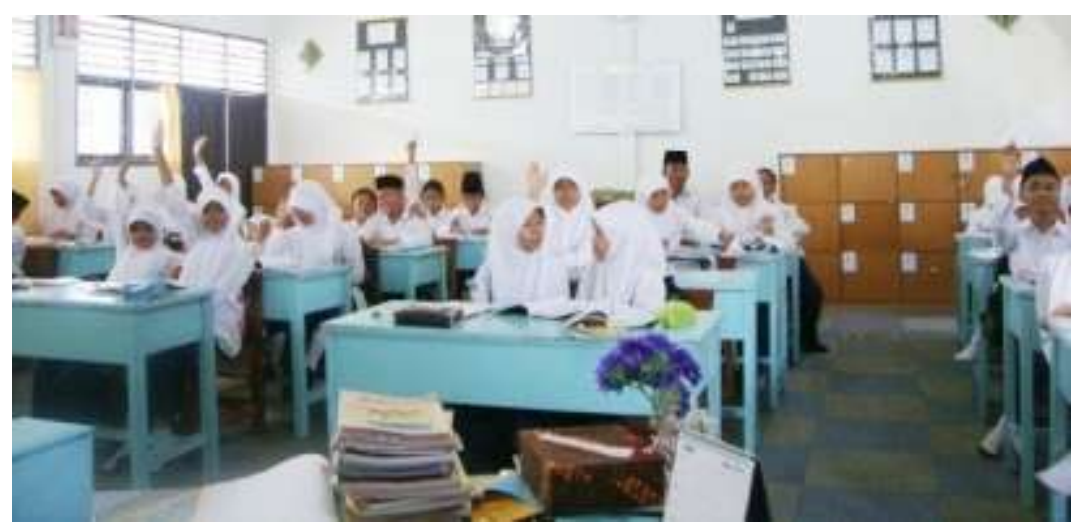

Gambar 4. Keaktifan Siswa dalam Pembelajaran 
ambar 4 menunjukkan keaktifan siswa dalam mengajukan diri untuk menunjukkan dan mengkomunikasikan hal yang telah mereka peroleh di depan kelasnya. Tampak siswa sangat percaya diri dan antusias dalam pembelajaran yang tengah berlangsung.

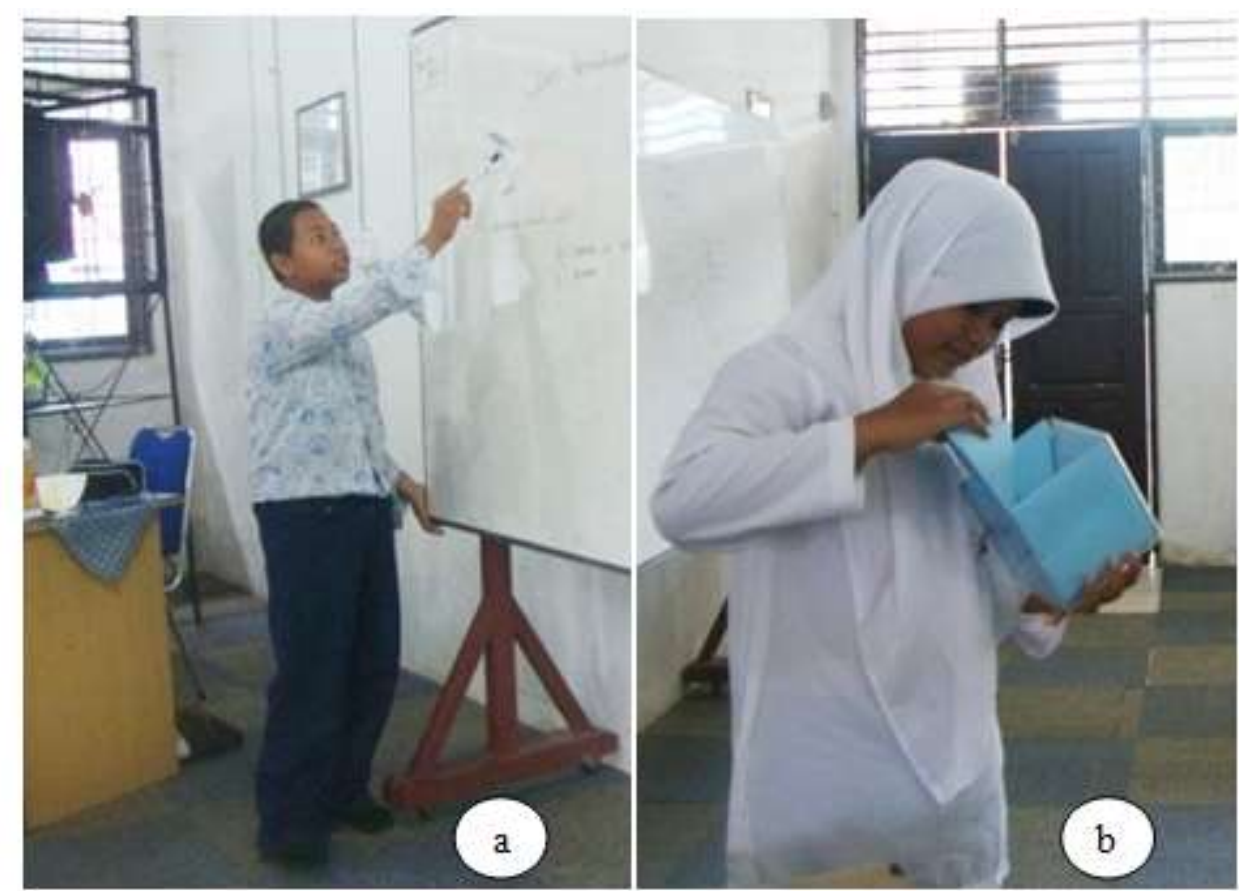

Gambar 5. Siswa Sedang Menyampaikan Ide dan Pemikirannya di Depan Kelas

Pada Gambar 5a merupakan gambar seorang siswa sedang mengemukakan idenya mengenai cara menemukan rumus luas permukaan kubus. Dan pada Gambar 5b, seorang siswa menunjukkan kepada temantemannya bahwa sebuah kubus dapat memuat enam buah limas segiempat beraturan yang panjang alasnya sama dengan panjang sisi kubus dan tinggi limas sama dengan setengah panjang sisi kubus, sehingga akhirnya ditemukan rumus umum untuk mencari volum limas.

Selama proses pembelajaran terlihat banyak siswa yang bersungguhsungguh mengikuti pembelajaran, menyenangi pelajaran matematika, lebih

Pengaruh ... (Erdawati Nurdin) memperhatikan guru saat memberikan penjelasan, aktif dalam kegiatan yang dilakukan, dan antusias dalam diskusi kelas. Hal ini dilihat dari angket skala sikap siswa yang menunjukkan sikap positif terhadap pendekatan pembelajaran visual thinking. Hal ini menguatkan pandangan Nicolaidou dan Philippou (2002) yang menyatakan bahwa sikap memiliki hubungan yang erat dengan kemampuan matematis siswa. Sidiqh (Depdiknas, 2005) menyebutkan bahwa minat dan sikap positif siswa berdampak terhadap munculnya sikap ulet dan percaya diri. Ditambahkan oleh Mohd dan Mahmood (2011) bahwa sikap positif, berupa kesabaran, rasa percaya 
diri dan harapan memberikan kontribusi terhadap pencapaian dalam matematika.

Sikap positif siswa ini tidak terlepas dari peran guru. Peran guru selama proses pembelajaran sangat berarti. Ketika siswa mengalami kesulitan dalam menemukan suatu rumus atau konsep, maka guru berperan dalam membimbing siswa, memberikan petunjuk-petunjuk yang mengarahkkan siswa untuk menemukan konsep atau rumus. Hal di atas sesuai dengan teori Vygotsky bahwa seorang anak membangun pengetahuannya lebih melalui sosiocultural (aspek eksternal). Vygotsky berpendapat bahwa perubahan pengetahuan siswa memerlukan bantuan yang diistilahkan dengan scaffolding. Bantuan ini dapat berupa petunjuk, dorongan, penguraian ataupun pertanyaan-pertanyaan yang mampu mendorong siswa menemukan suatu rumus ataupun konsep yang ingin dicapai dalam pembelajaran.

\section{Kesimpulan}

Berdasarkan hasil pengolahan data, analisis, temuan dan pembahasan yang telah disajikan secara umum dapat disimpulkan bahwa pembelajaran dengan pendekatan visual thinking berpengaruh positif terhadap sikap siswa.

\section{Pustaka}

Depdiknas. (2005). Panduan Materi Ujian Nasional. Jakarta: BPPPPP.
Djamarah, S. Bahri. 2008. Psikologi Belajar. Jakarta: Rineka Cipta.

Hodiyah, D. 2009. Implementasi Strategi Pembelajaran Think-Talk-Write Dalam Upaya Meningkatkan Kemampuan Berpikir Kreatif dan Koneksi Matematik Siswa SMA. Tesis tidak diterbitkan. Bandung: Tesis Pendidikan Matematika Universitas Pendidikan Indonesia.

Mohd, N, Mahmood, T dan Petri, T.F. 2011. The Effect of Attitude towards Problem Solving in Mathematics Achievements. Australian Journal of Basic and Applied Sciences. [Online]. Tersedia

http://www.insipub.com/ajbas/201 1/December-2011/1857-1862.pdf. [21 Juni 2012].

Nicolaidou, M dan Philippou, G. (2002). Attitude towards Mathematics, Self-Efficacy and Achievment in Problem Solving. Europian Research in Mathemtics Education III. [Online]. Tersedia : http://www.dm.unipi.it/ didattica/ CERME3/proceedings/Groups/T G2/TG2_nicolaidou_cerme3.pdf.[ 21 Juni 2012].

Ruseffendi, E.T. 2006. Pengantar kepada Membantu Guru Mengembangkan Kompetensinya dalam pembelajaran matematika untuk 
meningkatkan CBSA. Bandung : Tarsito.

Sugiyono. (2010). Metode Penelitian Pendidikan. Bandung : Alfabeta.

Thornton, S. 2001. A Picture is Worth A Thousand Words. [Online]. Tersedia: http://math.unipa.it/ grim/AThorn ton251.PDF [7 Oktober 2011].

Wahidin. 2010. Pengaruh Pembelajaran Berbantuan Alat Peraga terhadap Kemampuan Pemecahan Masalah Matematik Siswa SMP. Tesis Universitas Pendidikan Indonesia. Tidak Diterbitkan. 